\title{
APPLICABILITY OF THE DEVELOPMENTAL COORDINATION DISORDER QUESTIONNAIRE FOR CHILDREN IN SERBIA
}

\begin{abstract}
Špela GOLUBOVIĆ ${ }^{*}$
Sanja KALABA* Jasna MAKSIMOVIĆ**

*University of Novi Sad, Faculty of Medicine, Serbia ${ }^{* *}$ University of Kragujevac, Faculty of Education in Užice, Serbia
\end{abstract}

The aim was to evaluate the applicability of the Developmental Coordination Disorder Questionnaire (DCDQ) adapted for use on the population of children in Serbia. The sample consisted of 901 children (age range 60-168 months) who did not have problems with coordination and the clinical sample of 58 children (age range 60-108 months). The parents assessed their child's coordination rating it on a 5-point Likert scale. Internal consistency of the instrument was 0.94, item-correlations were as high as over 0.70, test-retest reliability was good $(r=0.97, p=0.00)$. The results revealed a significant positive correlation between the total questionnaire score and age $(r=0.28, p=0.00)$. Factor analysis confirmed three-factor structure. The questionnaire had good sensitivity (98\%) and specificity (78\%). The DCDQ applied on Serbian children has a potential to be a reliable and valid instrument for screening children with coordination problems.

Key words: developmental coordination disorder, assessment, clumsiness, cross-cultural adaptation

1 E-mail: spela.golubovic@mf.uns.ac.rs 
Specijalna edukacija i rehabilitacija (Beograd), Vol. 17, br. 4. 459-476, 2018.

\section{INTRODUCTION}

Results obtained from numerous studies have confirmed that developmental coordination disorder (DCD) is a neurodevelopmental condition which persists from childhood to adulthood (Blank, Smits-Engelsman, Polatajko, \& Wilson, 2012; Kirby, Sugden, \& Purcell, 2014). Incidence rates of DCD that have been reported in different studies range from $1.7 \%$ and 5\%-6\% to $19 \%$ in school-age children (American Psychiatric Association, 2013; Lingam, Hunt, Golding, Jongmans, \& Emond, 2009; Tsiotra et al., 2006).

Children with DCD show difficulties in performing motor activities, which is associated with a lack of motor coordination and which interferes with their academic achievement or activities of daily living. Motor coordination disorders are unrelated to general medical conditions such as cerebral palsy or intellectual disability (American Psychiatric Association, 2013).

The main observed features in DCD are clumsiness (American Psychiatric Association, 2013) and slowness (Farmer, Echenne, \& Bentourkia, 2016), but several other manifestations have been described as well, such as problems in performing different motor tasks, passivity and poor coordination, lack of fine motor skills, and difficulties in daily activities (Cairney \& Veldhuizen, 2013; Magalhães, Cardoso, \& Missiuna, 2011; Missiuna et al., 2014). Failure to perform motor tasks may lead to development of emotional and social difficulties (Cummins, Piek, \& Dyck, 2005). It is not unusual that there are more than one additional disorders present, such as attention deficit, language deficit, or overlapping motor problems (Goulardins et al., 2015; King-Dowling, Missiuna, Rodriguez, Greenway, \& Cairney, 2015). This impairment affects a child's academic performance and daily activities, and has an impact on an individual's growth and development (Hands, Licari, \& Piek, 2015). 

coordination disorder questionnaire for children in Serbia

The criteria for establishing a diagnosis of DCD have been changing over time; however, the new criteria for DCD were published in The Diagnostic Statistical Manual of Mental Disorders ( $5^{\text {th }}$ ed; DSM-5; American Psychiatric Association, 2013). In order to obtain a diagnosis of DCD, a child has to meet four diagnostic criteria. Smits-Engelsman (2015) summarized the use of DSM criteria and proposed a flowchart for the diagnosis of DCD, as well as terminology for DCD. The diagnosis requires the use of a norm-referenced motor test and the recommended cut-off scores of 15th percentile on a standardized test (Smits-Engelsman, Schoemaker, Delabastita, Hoskens, \& Geuze, 2015). However, an evaluation with these instruments is time-consuming, requires a special testing environment, trained staff, and furthermore, the tests are frequently unavailable due to their costs.

In order to detect children with DCD as early as possible and prevent possible future difficulties, it is strongly recommended that standardized questionnaires should be used as screening instruments which would be completed by parents or teachers, and thus provide additional information about motor function of a child. One of these specific screening instruments that assess coordination of movements in children is the parent-reported Developmental Coordination Disorder Questionnaire (DCDQ) (Wilson, 2007), developed to identify subtle motor problems in children aged 5-15 years. This questionnaire has been translated and cross-culturally adapted in several countries (http://www.DCDQ.ca/crosscutural-adaptations/es.html). The DCDQ proved to be a useful instrument for screening and monitoring change in children.

However, a thorough review of literature data showed that no research in Serbia had previously addressed psychometric properties of this questionnaire. We believed that a crosscultural adaptation of the DCDQ for the population of children in Serbia would enable easier recognition of children at risk for movement problems and in this way contribute to early intervention and prevention of further difficulties. 
Specijalna edukacija i rehabilitacija (Beograd), Vol. 17, br. 4. 459-476, 2018.

Therefore, the aim of this study was to evaluate applicability of this parents completed questionnaire and to investigate psychometric properties of the Serbian version of DCDQ.

\section{METHOD}

\section{Participants}

The sample consisted of a total of 959 children; out of whom 901 children had no problems with motor coordination, aged 5.0 - 14 years (age range in months 60-168; Mean=6 years 2 months; (SD 27.34)) and gender balanced (440 (48.9\%) boys and 461 (51.1\%) girls). There was no statistically significant difference between boys and girls in terms of age $\left(\chi^{2}=99.78\right.$; $\mathrm{p}=0.65)$. Control subjects were randomly recruited from public kindergartens and schools. The inclusion criteria were absence of any developmental disorders or other medical conditions that could have affected motor performance. The sample was formed of children from different regions in Serbia but greater part was from Vojvodina. We included children from urban and rural area.

The clinical group included 58 children aged 5-10 years (age range in months 60-108; Mean $=7$ years 8 months (SD 14.30) who were gender balanced (33 (56.9 \%) boys and 25 (43.1\%) girls). There was no statistically significant difference between boys and girls with regard to age $\left(\chi^{2}=37.95 p=0.15\right)$. Children were randomly recruited from rehabilitation centers and private therapy practices. All children had been diagnosed with impaired motor function as a result of manifested clumsiness, but without clinically relevant additional disorders, such as a specific neurological disease, cerebral palsy or intellectual disabilities. According to Smits-Engelsman and associates (2015) recommendations and proposed terminology for studies including DCD populations, we described this group of 

coordination disorder questionnaire for children in Serbia

children as 'a probable DCD' (p-DCD), due to the fulfillment of some but not all of the DSM- 5 criteria.

Sample distribution according to the age groups and the mean scores on the DCDQ is given in Table 1.

Two weeks after the initial assessment, 62 parents from the normative group and 36 parents from the clinical group were asked to complete the DCDQ again for testing the reliability of the questionnaire.

Instrument

TheDevelopmentalCoordinationDisorderQuestionnaire (DCDQ) (Wilson, 2007) is used to get information from parents about their child's motor performance. Parents assess their child's coordination in comparison with other children of the same age and rate it on a 5-point Likert scale. The DCDQ consists of 15 items grouped into three areas: control during movement, fine motor skills/handwriting, and general coordination. Total score ranges from 15 to 85 , with the cutoff scores provided to support "indication of DCD", "suspect DCD", or "probably not DCD". The DCDQ presented here is considered to have good psychometric properties. As reported in an earlier study (Wilson et al., 2009) Cronbach's alpha was 0.89 ; corrected item-total correlations ranged from 0.42 to 0.67 ; concurrent validity of the DCDQ revealed moderate but significant correlations (range of correlations of 0.40 to 0.60 ) with other standardized tests of motor skills. It was also found that the agreement between them was very high when identifying children who were non-DCD, but low when identifying those with DCD (Crawford, Wilson, \& Dewey, 2001). The three factors structure is found in the DCDQ. Overall sensitivity is $84.6 \%$ and specificity is $70.8 \%$ when using age related cutoff scores (Wilson et al., 2009). These psychometrics results are evident and similar in many other cross cultural DCDQ adaptations (http://www.DCDQ.ca/ cross-cutural-adaptations/es.html). 
The questionnaire was translated in accordance with the guidelines provided by Beaton et al. (Beaton, Bombardier, Guillemin, \& Ferraz, 2000). The questionnaire was translated twice into Serbian by two independent professionals who have different professional backgrounds and profiles (one translator has knowledge of the concepts assessed by the instrument and the other is not related to the health area). The questionnaire was adapted culturally to maintain content validity. Some adaptations were straightforward (converting feet to meters, finding equivalent phrase for the idiom "bull in a china shop"), while others proved to be more challenging. In some cases the whole phrases were replaced by single words ("hits an approaching ball"), and in one case a phrase was omitted in the translation into the target language ("appears to slouch"), as it was believed the particular item in the questionnaire was made clearer by omitting the description. The word "printing" proved somewhat challenging, as the Serbian language has a number of translations of that word that reveal nuances in meaning. The pre-final version in Serbian was done by two translators, a proofreader and an observer, who reviewed both versions and reached an agreement about it. The pre-final version in Serbian was then back translated by two English language professionals, blinded to the original version, after which translators and an observer produced a common translation in English. This version was approved by the author of the DCDQ (B. Wilson).

The final stage was a pilot research - a probe testing on a sample of 50 parents, and the questionnaire showed good characteristics and also served for minor language improvements made according to parents' suggestions.

This resulted in the final version of the Serbian adaptation of DCDQ (DCDQ-SR). 

coordination disorder questionnaire for children in Serbia

\section{Procedure}

The study was approved by the Ethics Committee of the Faculty of Medicine of the University of Novi Sad (Decision No. 01-1709/1). School administrators were informed about the aim and course of this study. Parents or legal guardians were given oral and written information about the purpose of the study, and only those who gave a written consent for their child were enrolled in the study. They had an opportunity to fill in the questionnaire at place of their convenience, i.e., at home, school or institution, and they returned it to the teacher or nurse.

\section{Statistical analysis}

The obtained data were analyzed with IBM, SPSS, version 24. Descriptive statistics was used to describe the sample.

Internal consistency of the DCDQ was estimated using Cronbach's alpha, inter-item and item-total correlations. In the interpretation of results, Cronbach' alpha was considered acceptable if above 0.7 and good if above 0.8 (Bruton, Conway, \& Holgate, 2000).

Construct validity was examined by exploratory factor analysis with varimax rotation.

The effects of gender and age and their interaction on DCDQ were tested using linear regression. Discriminative validity was tested with t-test for independent samples. Sensitivity and specificity were assessed using the area under receiver operating characteristic (ROC) curve.

Test-retest reliability was tested using Pearson's correlation coefficient. Correlation up to 0.29 was considered low, up to 0.49 moderate and above 0.50 high (Cohen, 1988). 
Specijalna edukacija i rehabilitacija (Beograd), Vol. 17, br. 4. 459-476, 2018.

\section{RESULTS}

The number of subjects with regard to age and mean questionnaire scores are presented in Table 1.

Table 1 - Sample distribution according to age groups and mean DCDQ scores

\begin{tabular}{|c|c|c|c|c|c|}
\hline \multicolumn{3}{|c|}{ Non-DCD } & \multicolumn{3}{|c|}{$p-D C D$} \\
\hline $\begin{array}{l}\text { Number of } \\
\text { participants }\end{array}$ & $\begin{array}{c}\text { Age in } \\
\text { months } \\
\text { Mean(SD) }\end{array}$ & $\begin{array}{c}\text { Score on DCDQ } \\
\text { Mean(SD) } \\
\text { (Range) }\end{array}$ & $\begin{array}{l}\text { Number of } \\
\text { participants }\end{array}$ & $\begin{array}{c}\text { Age in } \\
\text { months } \\
\text { Mean(SD) }\end{array}$ & $\begin{array}{l}\text { Score on } \\
\text { DCDQ } \\
\text { Mean(SD) } \\
\text { (Range) }\end{array}$ \\
\hline 185 & 64.75 (3.71) & $\begin{array}{c}62.43(9.01) \\
15-75\end{array}$ & 24 & 64.25 (3.56) & $\begin{array}{c}30.96(6.84) \\
22-47\end{array}$ \\
\hline 104 & 76.62 (3.15) & $\begin{array}{c}64.4(8.02) \\
36-75\end{array}$ & 17 & $77.53(3.06)$ & $\begin{array}{c}31.71(9.41) \\
19-58\end{array}$ \\
\hline 132 & $88.06(3.27)$ & $\begin{array}{c}64.43(10.37) \\
21-75\end{array}$ & 7 & $89.29(2.75)$ & $\begin{array}{c}40.86(6.93) \\
30-52\end{array}$ \\
\hline 153 & $101.51(3.24)$ & $\begin{array}{c}66.59(8.01) \\
16-75\end{array}$ & 8 & 100.38 (3.06) & $\begin{array}{c}34.13(10.98) \\
19-49\end{array}$ \\
\hline 118 & 112.76 (3.59) & $\begin{array}{c}66.24(8.41) \\
15-75\end{array}$ & 2 & $108.00(0.00)$ & $\begin{array}{c}41.00(5.65) \\
37-45\end{array}$ \\
\hline 91 & 125.48 (3.49) & $\begin{array}{c}67.53(8.37) \\
20-75\end{array}$ & & & \\
\hline 47 & 135.09 (3.18) & $\begin{array}{c}67.0(8.07) \\
44-75\end{array}$ & & & \\
\hline 33 & $149.42(3.80)$ & $\begin{array}{c}69.09(8.47) \\
37-75\end{array}$ & & & \\
\hline 38 & 161.00 (4.04) & $\begin{array}{c}69.21(7.04) \\
43-75 \\
\end{array}$ & & & \\
\hline
\end{tabular}

Internal consistency of the instrument (Cronbach's alpha coefficient) was 0.94 for the whole sample. In order to assess reliability of items, we calculated the item-total correlation. All correlations were acceptable and very high (above 0.60 ), except for the items 14 and 15 ( 0.58 and 0.59 , respectively) (Table 2 ). Inter-item correlation was also satisfactory, and ranged from 0.38 to 0.78 . 
Golubović, Š., Kalaba, S., Maksimović, J.: Applicability of the developmental coordination disorder questionnaire for children in Serbia

Table 2 - Item-total correlation

\begin{tabular}{lccc}
\hline Item & $\begin{array}{c}\text { Item-Total } \\
\text { Correlation }\end{array}$ & $\begin{array}{c}\text { Squared Multiple } \\
\text { Correlation }\end{array}$ & $\begin{array}{c}\text { Cronbach's Alpha } \\
\text { if Item Deleted }\end{array}$ \\
\hline Throws ball & 0.78 & 0.69 & 0.94 \\
\hline Catches ball & 0.74 & 0.67 & 0.94 \\
\hline Hits ball & 0.71 & 0.60 & 0.94 \\
\hline Jumps over & 0.74 & 0.67 & 0.94 \\
\hline Runs and stops & 0.75 & 0.67 & 0.94 \\
\hline Plan activity & 0.76 & 0.64 & 0.94 \\
\hline Writing fast & 0.75 & 0.70 & 0.9 \\
\hline Writing legibly & 0.70 & 0.68 & 0.94 \\
\hline Effort and pressure & 0.63 & 0.50 & 0.94 \\
\hline Cuts & 0.72 & 0.59 & 0.94 \\
\hline Like time spots & 0.74 & 0.63 & 0.94 \\
\hline Learning new skills & 0.75 & 0.61 & 0.94 \\
\hline Quick/competent & 0.73 & 0.56 & 0.94 \\
\hline Bull in china & 0.58 & 0.54 & 0.94 \\
\hline Fatigues easily & 0.59 & 0.54 & 0.94 \\
\hline
\end{tabular}

The test-retest reliability was investigated on a sample of 98 subjects using Pearson's correlation coefficient. There was a strong positive correlation between the first and the repeated test $(\mathrm{r}=0.97, \mathrm{p}=0.00)$. Kappa measure of agreement was 0.36 , $\mathrm{p}=0.00$ indicating that the questionnaire had a good test-retest reliability.

Exploratory factor analysis was employed in order to determine the structure of the questionnaire. In order to verify that the research sample was appropriate and suitable for factorization, the following analyses were performed. KaiserMeyer-Olkin test of the adequacy of the sample for the factor analysis was 0.94 , which was highly satisfactory. Bartlett's sphericity test was also satisfactory $(10506.40, \mathrm{p}=0.00)$. After the suitability of the sample was determined, further analysis was carried out. Exploratory factor analysis showed the existence of three factors. The first factor accounted for the highest percentage of explained variance $(35.26 \%)$, while the other two factors explained lower percentages of variance $(22.73 \%$ and $13.77 \%$, respectively). Table 3 presents contribution of the items to each of the three factors after varimax rotation. 
Specijalna edukacija i rehabilitacija (Beograd), Vol. 17, br. 4. 459-476, 2018.

Table 3 - Contribution of items to rotated factors

\begin{tabular}{lccc}
\hline \multirow{2}{*}{ Item } & \multicolumn{3}{c}{ Factor } \\
\cline { 2 - 4 } & 1 & 2 & 3 \\
\hline Throws ball & $\mathbf{0 . 7 9}$ & 0.29 & 0.18 \\
\hline Catches ball & 0.77 & 0.26 & 0.16 \\
\hline Hits ball & $\mathbf{0 . 7 0}$ & 0.30 & 0.17 \\
\hline Jumps over & $\mathbf{0 . 8 0}$ & 0.22 & 0.18 \\
\hline Runs and stops & $\mathbf{0 . 7 3}$ & 0.31 & 0.22 \\
\hline Plan activity & $\mathbf{0 . 6 8}$ & 0.41 & 0.19 \\
\hline Writing fast & 0.39 & $\mathbf{0 . 7 8}$ & 0.16 \\
\hline Writing legibly & 0.29 & $\mathbf{0 . 8 4}$ & 0.14 \\
\hline Effort and pressure & 0.22 & $\mathbf{0 . 7 6}$ & 0.23 \\
\hline Cuts & 0.42 & $\mathbf{0 . 7 0}$ & 0.15 \\
\hline Like time spots & $\mathbf{0 . 7 3}$ & 0.26 & $\mathbf{0 . 2 6}$ \\
\hline Learning new skills & 0.68 & 0.29 & $\mathbf{0 . 3 2}$ \\
\hline Quick/competent & $\mathbf{0 . 5 4}$ & 0.42 & $\mathbf{0 . 3 3}$ \\
\hline Bull in china & 0.27 & 0.19 & $\mathbf{0 . 8 4}$ \\
\hline Fatigues easily & 0.27 & 0.20 & $\mathbf{0 . 8 5}$ \\
\hline
\end{tabular}

The results showed that the assumed structure of the questionnaire was confirmed. The first factor (control during movement) was described by the first six items, the second factor (fine motor skills) was described by the following four items, and the third factor (general coordination) was described by the remaining items of the questionnaire.

Discriminant validity was tested by t-test. Of the total number of non-DCD children, 34 (5.70\%) had an indication of DCD, whereas 44 (75.9\%) of p-DCD children had an indication of the DCD diagnosis.

In order to determine the sensitivity and specificity of the questionnaire, we applied the ROC analysis, which yielded the sensitivity of $98 \%$ and specificity of $78 \%$, which is consistent with the recommended standards for a satisfactory diagnostic test.

In order to balance the sample, we formed a subsample of non-DCD children $(n=594)$ matched for age and gender with $\mathrm{p}-\mathrm{DCD}$ children $(\mathrm{n}=58)$. This sub-sample is used for comparison across the two groups. In addition, we were interested in differences in the total scores between controls and $\mathrm{p}$-DCD children. Children from the non-DCD group achieved significantly higher overall scores $\mathrm{M}=64.47$ (SD 8.98) 
in comparison with $\mathrm{p}-\mathrm{DCD}$ children $\mathrm{M}=33.16$ (SD 8.74), with a statistically significant difference $(\mathrm{t}=25.39 \mathrm{p}=0.00)$. These results confirmed good discriminant validity of the instrument.

The association of gender and age with the DCDQ score was tested by linear regression (Table 4). The girls had higher scores on the questionnaire $\mathrm{M}=65.38$ (SD 9.15) compared to boys $\mathrm{M}=63.65$ (SD 9.18) but the difference was not significant. There was a significant positive correlation between the total score and age $(\mathrm{r}=0.22, \mathrm{p}=0.00)$ and not a significant correlation between gender and the total score.

Table 4 - The association between gender and age and DCDQ score

\begin{tabular}{|c|c|c|c|c|c|c|c|c|}
\hline Area & $\mathrm{R}$ & $\mathrm{F}$ & $p$ & Variable & $\mathrm{B}$ & Beta & $t$ & $p$ \\
\hline \multirow{2}{*}{ Total coordination } & \multirow{2}{*}{0.22} & \multirow{2}{*}{17.50} & \multirow{2}{*}{0.00} & gender & 1.82 & 0.07 & 1.89 & 0.06 \\
\hline & & & & age & 0.17 & 0.21 & 5.53 & 0.00 \\
\hline
\end{tabular}

\section{DISCUSSION}

The aim of our study was to construct a cross-cultural adaptation of the Developmental Coordination Disorder Questionnaire for the Serbian-speaking region, and thereby enable its use in Serbia as well as in neighboring countries due to the same language and cultural background.

Translation of the original questionnaire was done in accordance with the translation recommendations, taking into account the linguistic and cultural differences. Overall, we strived to strike a balance between preserving the original content, finding precise semantic and grammatical equivalents and making the questionnaire easily understandable to the general population in the target language.

Our results showed an extremely high reliability (0.94) for the whole questionnaire, which is consistent with the results of previous studies on reliability of this questionnaire (Girish, Raja, \& Kamath, 2016; Hua et al., 2015; Nowak, 2016; Wilson et al., 2009) where the Cronbach alpha is higher than 0.80 . 
We found a high item-total correlation for the whole questionnaire, except for items 14 and 15, which deserve special attention. Item 14, the phrase "bull in a china shop", refers to the assessment of overall coordination of the child. It is possible that parents did not understand this idiom correctly, and that instead of overall coordination, they assessed the child's precision and carefulness in some specific situations e.g. only when the child is in narrow or fragile place. Item 15 refers to muscle tone and stability of the child. The lower item-total correlation found for this item may be explained by the increasingly prevalent sedentary lifestyle, or by parents accustomed to children mainly spending their free time sitting in front of a computer or TV, without physical activity, so that they did not perceive the child's stability and posture as problematic.

The good test-retest reliability and low variability demonstrated on repeated testing after two weeks in our study, proved the instrument to be reliable even over time. In earlier studies (Martini, St-Pierre, \& Wilson, 2011; Tseng et al., 2010) test-retest reliability were 0.90 to 0.97 which is confirmed in our study.

Exploratory factor analysis showed the existence of three factors. The three-factor solution, although with a different item distribution, is consistent with previous research (Girish et al., 2016). The first factor describes the first six items, the second factor describes the next four items, and the third factor describes the remaining items in the questionnaire. However, we noticed a difference in the distribution of the following three items of the first factor: Item 11 "Your child is interested in and likes to participate in sports games or activities which require good motor skills.“; item 12 „Your child easily learns new motor tasks (e.g. swimming, rollerblading) and does not require more practice or time than other children to achieve the same level of skill"; and item 13 "Your child is fast and skillful in tidying up, putting on shoes, tying shoelaces, dressing, etc."which in our sample had a greater contribution to explaining the first factor $(0.73 ; 0.68$ and 0.54 , respectively), i.e., the factor dealing with control during movement. 

coordination disorder questionnaire for children in Serbia

The three factors singled out in our study may be explained by cultural differences related to parents' perception of the expected child's interest and involvement in sports activities, and considering that no research was done in our region that used DCDQ as a measuring instrument, we are not able to compare our results with relevant results obtained in a social and cultural environment similar to ours.

Analysis shows that $5.70 \%$ of the total number of nonDCD children had an indication of DCD. Literature shows inconsistent data about estimation of DCD because prevalence is directly related to the manner in which assessment is conducted and the establishment of cut-off points. It is estimated that $6 \%$ of the world population is affected by DCD thus our result that $5.7 \%$ of the controls would have an indication of DCD is expected.

The sensitivity of the DCDQ, on our sample, was satisfactory, as well as the specificity and are in agreement with other observations (Wilson et al., 2009) or even higher. In addition, the observed significant and positive correlation between the total score and age suggests that it is important to consider age when using DCDQ cut-offs.

Finally, our results are in agreement with other studies (Capone et al., 2007; Caravale, Baldi, Gasparini, \& Wilson, 2014; Prado, Magalhães, \& Wilson, 2009) confirming that the DCDQ-SR may be a useful screening tool in early recognition of children suspected for motor coordination problems.

\section{Study limitations}

Clinical sample (p-DCD) fulfills some but not all of the DSM-5 criteria. Although whole sample size was relatively large, the small clinical sample limited statistical analysis. The sample should be formed from different regions in Serbia not mainly from Vojvodina. Matched comparison in all age groups would have been beneficial, but we did not have all age groups in the clinical sample. 
Specijalna edukacija i rehabilitacija (Beograd), Vol. 17, br. 4. 459-476, 2018.

\section{Conclusion}

The DCDQ-SR applied to children in Serbia has the potential to be a reliable and valid instrument for screening children with coordination problems. However, it is necessary to carry out further research to test the concurrent validity of the instrument as well as the possibility of its application with younger children.

\section{REFERENCES}

1. American Psychiatric Association (APA). (2013). Diagnostic and Statistical Manual of Mental Disorders. Washington, DC. (5th ed.).

2. Beaton, D.E., Bombardier, C., Guillemin, F., \& Ferraz, M. B. (2000). Guidelines for the Process of Cross-Cultural Adaptation of SelfReport Measures. Spine, 25(24), 3186-3191. doi:10.1097/00007632200012150-00014

3. Blank, R., Smits-Engelsman, B., Polatajko, H., \& Wilson, P. (2011). European Academy for Childhood Disability (EACD): Recommendations on the definition, diagnosis and intervention of developmental coordination disorder (long version). Developmental Medicine \& Child Neurology, 54(1), 54-93. doi:10.1111/j.1469-8749.2011.04171.x

4. Bruton, A., Conway, J. H., \& Holgate, S. T. (2000). Reliability: What is it, and how is it measured. Physiotherapy, 86(2), 94-99. doi:10.1016/s0031-9406(05)61211-4

5. Cairney, J., \& Veldhuizen, S. (2013). Is developmental coordination disorder a fundamental cause of inactivity and poor health-related fitness in children. Developmental Medicine \& Child Neurology, 55(Suppl. 4), 55-58. doi:10.1111/dmcn.12308

6. Caravale, B., Baldi, S., Capone, L., Presaghi, F., Balottin, U., \& Zoppello, M. (2015). Psychometric properties of the Italian version of Developmental Coordination Disorder Questionnaire 2007 (DCDQ'07): A preliminary study / Proprietà psicometriche della versione italiana del Developmental Coordination Disorder 
Golubović, Š., Kalaba, S., Maksimović, J.: Applicability of the developmental coordination disorder questionnaire for children in Serbia

Questionnaire 2007 (DCDQ'07): Uno studio preliminare. Psicologia Clinica Dello Sviluppo, 36, 543-550. doi:10.1016/j.ridd.2014.10.035

7. Caravale, B., Baldi, S., Gasparini, C., \& Wilson, B. N. (2014). Crosscultural adaptation, reliability and predictive validity of the Italian version of Developmental Coordination Disorder Questionnaire (DCDQ). European Journal of Paediatric Neurology, 18(3), 267-272. doi:10.1016/j.ejpn.2013.11.009

8. Cohen, J. (1988). Statistical Power Analysis for the Behavioral Sciences. Hillsdale, N. J.: Lawrence Erlbaum. 2nd Edition.

9. Crawford, S. G., Wilson, B. N., \& Dewey, D. (2001). Identifying Developmental Coordination Disorder: Consistency between Tests. Physical \& Occupational Therapy In Pediatrics, 20(2-3), 29-50. doi:10.1080/j006v20n02_03

10. Cummins, A., Piek, J. P., \& Dyck, M. J. (2005). Motor coordination, empathy, and social behaviour in school-aged children. Developmental Medicine \& Child Neurology, 47(7), 437-442. doi:10.1017/s001216220500085x

11. Farmer, M., Echenne, B., \& Bentourkia, M. (2016). Study of clinical characteristics in young subjects with Developmental coordination disorder. Brain and Development, 38(6), 538-547. doi:10.1016/j.braindev.2015.12.010

12. Girish, S., Raja, K., \& Kamath, A. (2016). Translation of revised version of developmental coordination disorder questionnaire (DCDQ'07) into Kannada-Results of validation. Asia Pacific Disability Rehabilitation Journal, 26(4), 82-100. doi:10.5463/dcid.v26i4.442

13. Goulardins, J. B., Rigoli, D., Licari, M., Piek, J. P., Hasue, R. H., Oosterlaan, J., \&Oliveira, J.A. (2015). Attention deficithyperactivity disorder and developmental coordination disorder: Two separate disorders or do they share a common etiology. Behavioural Brain Research, 292, 484-492. doi:10.1016/j.bbr.2015.07.009

14. Hands, B., Licari, M., \& Piek, J. (2015). A review of five tests to identify motor coordination difficulties in young adults. Research in Developmental Disabilities, 41(42), 40-51. doi:10.1016/j.ridd.2015.05.009

15. Hua, J., Gu, G., Zhu, Q., Wo, D., Liu, M., Liu, J., ... Duan, T. (2015). The reliability and validity of the Developmental Coordination 
Specijalna edukacija i rehabilitacija (Beograd), Vol. 17, br. 4. 459-476, 2018.

Disorder Questionnaire'07 for children aged 4-6 years in mainland China. Research in Developmental Disabilities, 47, 405-415. doi:10.1016/j.ridd.2015.10.006

16. King-Dowling, S., Missiuna, C., Rodriguez, M. C., Greenway, M., \& Cairney, J. (2015). Co-occurring motor, language and emotionalbehavioral problems in children 3-6years of age. Human Movement Science, 39, 101-108. doi:10.1016/j.humov.2014.10.010

17. Kirby, A., Sugden, D., \& Purcell, C. (2013). Diagnosing developmental coordination disorders. Archives of Disease in Childhood, 99(3), 292-296. doi:10.1136/archdischild-2012-303569

18. Lingam, R., Hunt, L., Golding, J., Jongmans, M., \& Emond, A. (2009). Prevalence of Developmental Coordination Disorder Using the DSM-IV at 7 Years of Age: A UK Population-Based Study. Pediatrics, 123(4), doi:10.1542/peds.2008-1770

19. Magalhães, L. C., Cardoso, A. A., \& Missiuna, C. (2011). Activities and participation in children with developmental coordination disorder: A systematic review. Research in Developmental Disabilities, 32(4), 1309-1316. doi:10.1016/j.ridd.2011.01.029

20. Martini, R., St-Pierre, M., \& Wilson, B. N. (2011). French Canadian Cross-Cultural Adaptation of the Developmental Coordination Disorder Questionnaire '07: DCDQ-FC. Canadian Journal of Occupational Therapy, 78(5), 318-327. doi:10.2182/cjot.2011.78.5.7

21. Missiuna, C., Cairney, J., Pollock, N., Campbell, W., Russell, D. J., Macdonald, K., . . . Cousins, M. (2014). Psychological distress in children with developmental coordination disorder and attentiondeficit hyperactivity disorder. Research in Developmental Disabilities, 35(5), 1198-1207. doi:10.1016/j.ridd.2014.01.007

22. Nowak, A. (2016). Cross-cultural adaptation of the Developmental Coordination Disorder Questionnaire (DCDQ'07) for the population of Polish children. Biomedical Human Kinetics, 8(1), 17-23. doi:10.1515/bhk-2016-0003

23. Prado, M., Magalhães, L., \& Wilson, B. (2009). Cross-cultural adaptation of the Developmental Coordination Disorder Questionnaire for brazilian children / Adaptação transcultural do questionário de transtorno do desenvolvimento da coordenação para crianças brasileiras. Revista Brasileira De Fisioterapia, 13(3), 236-243. doi:10.1590/s1413-35552009005000024 

coordination disorder questionnaire for children in Serbia

24. Smits-Engelsman, B., Schoemaker, M., Delabastita, T., Hoskens, J., \& Geuze, R. (2015). Diagnostic criteria for DCD: Past and future. Human Movement Science, 42, 293-306. doi:10.1016/j.humov.2015.03.010

25. Tseng, M., Fu, C., Wilson, B.N., \& Hu, F. (2010). Psychometric properties of a Chinese version of the Developmental Coordination Disorder Questionnaire in community-based children. Research in Developmental Disabilities, 31(1), 33-45. doi:10.1016/j.ridd.2009.07.018

26. Tsiotra, G. D., Flouris, A. D., Koutedakis, Y., Faught, B. E., Nevill, A. M., Lane, A. M., \& Skenteris, N. (2006). A Comparison of Developmental Coordination Disorder Prevalence Rates in Canadian and Greek Children. Journal of Adolescent Health, 39(1), 125-127. doi:10.1016/j.jadohealth.2005.07.011

27. Wilson, B. (2007). The developmental coordination disorder questionnaire (DCDQ'07) Administration manual for the DCDQ'07 with psychometric properties. Retrieved from http:// www.DCDQ'07.ca.

28. Wilson, B. N., Crawford, S. G., Green, D., Roberts, G., Aylott, A., \& Kaplan, B. J. (2009). Psychometric Properties of the Revised Developmental Coordination Disorder Questionnaire. Physical \& Occupational Therapy In Pediatrics, 29(2), 182-202. doi:10.1080/01942630902784761 


\title{
PRIMENJIVOST UPITNIKA ZA PROCENU RAZVOJNOG POREMEĆAJA KOORDINACIJE KOD DECE U SRBIJI
}

\author{
Špela Golubović*, Sanja Kalaba*, Jasna Maksimović ${ }^{* *}$ \\ *Univerzitet u Novom Sadu, Medicinski fakultet, Srbija \\ ** Univerzitet u Kragujevcu, Pedagoški fakultet u Užicu, Srbija
}

\begin{abstract}
Sažetak
Cilj ovog rada je da se ispita mogućnost primene Upitnika za procenu razvojnog poremećaja koordinacije (Developmental Coordination Disorder Questionnaire - DCDQ) kod dece u Srbiji. Ukupan broj ispitanika ( $\mathrm{N}=959)$ podeljen je $\mathrm{u}$ dve grupe, prvu je činilo 901 dete (uzrast u mesecima 60-168) koja nisu ispoljavala probleme koordinacije, a drugu 58 dece koja su činila klinički uzorak (uzrast u mesecima 60108). Roditelji su koordinaciju kod svog deteta ocenjivali na petostepenoj Likertovoj skali. Interna konzistentnost instrumenta iznosila je 0,94 , ajtem korelacija 0,70 , a test-retest pouzdanost $(r=0,97, p=0,00)$. Rezultati pokazuju da postoji značajna pozitivna korelacija između ukupnog skora na Upitniku i uzrasta deteta $(\mathrm{r}=0,28, \mathrm{p}=0,00)$. Faktorskom analizom dobijena je trofaktorska struktura Upitnika, koji ima dobru senzitivnost (98\%) i specifičnost (78\%). Na osnovu navedenih podataka može se zaključiti da je Upitnik za procenu razvojnog poremećaja koordinacije, pouzdan i validan skrining instrument i primenjiv na populaciji dece u Srbiji.

Ključne reči: razvojni poremećaj koordinacije procena, nespretnost, kros-kulturalna adaptacija
\end{abstract}

Primljeno: 23.07.2018.

Prihvaćeno: 21.10.2018. 